\title{
REPRESENTASI ORIENTALISME DALAM VIDEO MUSIK THIRTY SECONDS TO MARS FROM YESTERDAY
}

\author{
Dibba Nugroho $^{{ }^{*}, \text { Judy } \text { Djoko Wahjono Tjahjo }}{ }^{1}$, Megawati Wahjudianata ${ }^{1}$ \\ ${ }^{1}$ Prodi Ilmu Komunikasi, Universitas Kristen Petra Surabaya \\ Jl. Siwalankerto 121-131, Surabaya, INDONESIA \\ *Penulis korespondensi; Email: dibbanugroho@gmail.com
}

\begin{abstract}
ABSTRAK
From Yesterday merupakan video musik milik grup band asal Amerika, Thirty Seconds to Mars. Video musik ini merupakan video musik dari Amerika pertama yang melakukan proses shooting di hadapan rakyat Republik Cina dan mengambil lokasi di Forbidden City. Penelitian ini dilakukan untuk mengetahui bagaimana orientalisme digambarkan dalam video musik "From Yesterday". Metode yang digunakan dalam penelitian ini adalah semiotika John Fiske dengan 3 level, yaitu level realitas, level representasi dan level ideologi. Pendekatan yang dilakukan dalam penelitian ini adalah deskriptif kualitatif untuk mendeskripsikan tanda dan lambang dalam video musik tersebut. Berdasarkan hasil penelitian, peneliti menemukan bahwa bangsa Timur digambarkan sebagai sosok yang inferior dalam video musik ini. Hal tersebut terlihat dari bagaimana tanda dan lambang yang ada dalam video menunjukkan adanya pertanda: 1) Dominasi Barat terhadap Timur, 2) Stereotype Timur dari pandangan Barat yang semakin dikokohkan, dan 3) Pengabaian sejarah dari budaya-budaya Timur yang ada. Ideologi yang ditemukan peneliti dalam penelitian ini adalah ideologi ras.
\end{abstract}

Kata kunci: Representasi, Orientalisme, Video Musik, Semiotika.

\begin{abstract}
From Yesterday was a music video belongs to American band called Thirty Seconds to Mars. This music video was the first American music video that ever shot in front of the people of China Republic and took place in Forbidden City. This research is done to find out how orientalism is represented in "From Yesterday" music video. Therefore, researcher uses John Fiske's semiotic as an analysis method with three levels: reality level, representation level, and ideology level. The approach used in this research was qualitative descriptive to describe the signs and symbols in this music video.The result of this research was the Eastern (Orient) represented as an inferior figure. We can see that from the signs and symbols from this music video that shows: 1) Western domination, 2) The Orient's stereotype from the Occident's point of view being strongly confirmed, and 3) The ignorance of the background history behind eastern cultures that appears in the video. The ideology found in this research was race ideology.
\end{abstract}

Keywords: Representation, Orientalism, Music Video, Semiotics.

\section{PENDAHULUAN}

Pada musim gugur 2004, sebuah channel musik cabang dari MTV, Video Hits One (VH1) menyiarkan sebuah program spesial tentang tren baru dalam video musik. Dari top 100 video musik yang masuk, dapat terlihat ada banyak video musik dari musisi Hip-hop yang mengandung unsur budaya Asia. Walaupun komentator mengatakan bahwa etnisitas Asia dalam musik rap dan artis R\&B sedang "hits" di abad ke-21 ini, sebenarnya hal tersebut sudah digunakan bahkan dari awal era musik video (Hernandez \& Steen, 2006, p.188-189). Contohnya video musik dari band beraliran punk rock, The Vapors yang berjudul "Turning Japanese". Video musik ini cukup mengejutkan secara visual maupun linguistik. Terdapat sebuah adegan dimana para personil The Vapors memainkan sebuah pedang di depan seorang perempuan geisha Jepang dan bernyanyi "I think I'm turning 'Jap-a-nese-a', I think I'm turning Jap-anese-a', I really think so... no sex, no drugs, no wine, no women... everyone around me is a total stranger, everyone around me looks like a cyclone ranger, everyone".

Fenomena ini merupakan sebuah gambaran singkat tentang apa yang kita kenal sekarang dengan sebutan orientalisme. Secara singkat, orientalisme adalah cara pandang Barat kepada bangsa Timur. Dari fenomena video musik diatas, artis atau produsen video musik yang merupakan bangsa Barat, menggambarkan bangsa Timur menggunakan stereotype Barat atau cara pandang Barat melihat bangsa Timur. Stereotype yang muncul adalah bangsa Timur adalah bangsa 
yang rendah, tidak memiliki peradaban yang maju, kotor tidak seperti Barat. Hal tersebut terlihat dari pernyataan Edward Said mengenai kritiknya terhadap ketidakadilan bangsa Barat lewat karyanya "Orientalisme" yang menyebutkan bahwa orientalisme adalah cara Barat untuk mendominasi, merestrukturisasi, dan menguasai Timur (Said, 1978, p.3). Bangsa Barat menggambarkan bangsa Timur sebagai hal yang selalu terbelakang dan tidak lebih tinggi daripada Barat. Hal tersebut didukung dari pernyataan Edward Said bahwa karakter Orient bersifat irasional, rusak akhlak, kekanak-kanakan, mudah ditipu, tidak memiliki energi dan inisiatif, senang dipuji dan dijilat, penuh intrik, licik, kejam terhadap binatang, bodoh, terbelakang, pembohong yang senang berkilah, malas, penuh prasangka buruk, mudah dikalahkan, bertele-tele dalam menyampaikan buah pikirannya dan berbeda. Hal itu berbeda dengan karakter Barat yang digambarkan rasional, jelas, tepat, mulia, penuh kebajikan, matang, digjaya, jernih dalam mengungkapkan buah pikirannya dan normal (Said, 1978,p. 40).

Unsur Orientalisme marak di media massa, salah satunya adalah video musik. Video musik sendiri merupakan bentuk yang signifikan dan menarik dari budaya popular kontemporer ( video musik dalam budaya populer tak lepas dari munculnya Music Television (MTV) pada tahun 1981. Akan tetapi, kini para konsumen video musik memiliki lebih banyak pilihan yang tersedia untuk melihat sebuah video musik selain dari televisi mereka. Situs seperti You Tube, atau aplikasi seperti Apple iTunes memungkinkan para konsumer untuk mengakses video musik dimana saja dan kapan saja. Kini para produsen video musik tidak berhenti berlomba-lomba untuk memproduksi sebuah video musik sekreatif dan seberagam mungkin. Konten dan pesan yang disampaikan lewat video musik pun kini semakin beragam. Contoh video yang mengandung orientalisme adalah video musik Coldplay dan Rihanna yang berjudul Princess of China. Di dalam video tersebut Rihanna dan Chris Martin (vokalis Coldplay) menggunakan atribut dan pakaian yang bernuansa Asia. Atribut yang digunakan tidak hanya berasal dari budaya Cina, melainkan juga bercampur dengan budaya negara Asia lainnya, yaitu Jepang (Samurai), Thailand (tarian), dan India (pakaian). Di dalam teks ini, Barat kerap kali mencampuradukkan penggambaran budaya Timur dari beberapa negara tanpa melihat latar belakang asal-usul sejarah dari budaya masing-masing negara tersebut.

Selain video musik, orientalisme juga kerap terlihat dalam film-film Hollywood. Menurut Jane Chi Hyun
Park, film Hollywood akhir-akhir ini 'membantu' membentuk image baru dari bangsa Asia Timur (Park, 2010). Contoh film yang merepresentasikan perjalanan pencitraan Asia Timur adalah The Karate Kid dan kelima sekuelnya. Penggambaran orientalisme dalam film The Karate Kid remake 2010 telah diteliti oleh Fekie Manalib dari Universitas Kristen Petra pada tahun 2011 dalam penelitiannya yang berjudul "Representasi orientalisme pada film The Karate Kid Remake 2010". Dalam penelitian tersebut, Fekie membahas bagaimana film The Karate Kid remake 2010 menggambarkan Orientalisme dengan cara yang berbeda sehingga lebih tersamarkan, bahkan tidak terlihat kasat mata. Penelitian ini berfokus pada fenomena Oriental Style yang hanya menjadi dekorasi pada film The Karate Kid remake 2010 dan mengacuhkan proses dan sejarahnya.

Ironisnya, terkadang kita bangsa Timur juga mengamini dan mengiyakan bahwa posisi barat lebih tinggi daripada timur. Contoh lain dapat dilihat dari industri musik Indonesia, Agnes Monica misalnya. Menurut Felita Fedelia dalam penelitiannya pada tahun 2012 yang berjudul "Westernized Agnes: Sepotong Paradoks tentang Konstruksi Image Agnes Monica", penyanyi muda asal Indonesia tersebut sedang mengkonstruksikan image-nya sebagai penyanyi muda Indonesia yang berstandar Internasional atau Barat (dalam hal ini Amerika) melalui berbicara dan berbahasa, pilihan fashion, performance/ stage act, serta sikap perfeksionismenya. Melalui hal-hal tersebut, Agnes Monica mengkonstruksi citra dirinya sebagai penyanyi yang berbeda (lebih unggul, superior, dominan), dibanding penyanyi Indonesia lainnya karena selalu menggunakan standar Barat dalam penampilannya. Video musik Coke Bottle milik Agnes Monica contohnya. Agnes menggaet rapper asal Amerika dan melakukan proses produksi musik di Amerika pula. Walaupun di dalamnya ia menggunakan atribut khas Indonesia, yaitu batik, akan tetapi penggunaan batik sudah dimodifikasi menjadi lebih modern dan mengikuti zaman daripada bentuk aslinya. Mengingat video klip tersebut juga sudah go international dan sudah menjadi objek tontonan orang-orang di luar Indonesia pula, termasuk barat. Budaya Asia yang ada di dalam video seakan-akan hanya sebagai atribut pelengkap video. Penelitian ini dipilih oleh peneliti sebagai penelitian terdahulu untuk menujukkan bagaimana orientalisme dan pengaruhnya telah masuk ke Timur, terlebih juga ke Indonesia.

Hal diatas juga ditemui peneliti dalam video musik From Yesterday dari Thirty Seconds to Mars. Video musik From Yesterday sendiri berhasil memenangkan 
Kerrang! Award untuk kategori Best Single. Video berdurasi 7 menit ini dirilis pada tahun 2006 dibawah label Virgin Records, Amerika. Peneliti memilih untuk meneliti video ini karena didalamnya banyak terdapat tanda dan lambang yang diduga peneliti merepresentasikan adanya orientalisme.

Thirty Seconds to Mars (30STM) merupakan sebuah band yang berasal dari Los Angeles, Amerika yang beranggotakan Jared Leto (vokal, gitar, keyboard), Shannon Leto (drum), Tomo Miličević (gitar, bass). Band dengan aliran rock ini menjadi band Amerika pertama yang memproduksi video musik di depan hadapan masyarakat Republik Cina dan berlatarkan di Istana Kaisar Cina atau Forbidden City. Video musik yang disutradarai oleh frontman dari Thirty Seconds to Mars sendiri, yaitu Jared Leto (Leahey, 2014) mengatakan bahwa video musik From Yesterday terinspirasi dari film The Last Emperor tahun 1987, dimana bercerita tentang perjalanan para personil Thirty Seconds to Mars ke negeri Cina. Sebenarnya, mereka datang ke Cina bukan karena kemauan mereka sendiri, akan tetapi karena sang kaisar yang meminta mereka untuk datang dalam rangka merayakan ulang tahunnya. Peneliti melihat bahwa dalam video musik tersebut terdapat beberapa hal yang menandakan adanya pandangan stereotype Barat kepada Timur di beberapa adegan. Seperti ketika para personil dibawa berkeliling istana dan menemui beberapa aktivitas dan ritual yang mengejutkan mereka. Peneliti ingin melihat bagaimana bangsa timur digambarkan dalam video From Yesterday dengan melihat representasi dari tanda dan lambang yang ada dalam teks tersebut. Oleh karena itu, peneliti akan menggunakan metode Semiotika, khususnya kode-kode televisi oleh John Fiske.

\section{TINJAUAN PUSTAKA}

\subsection{Orientalisme}

Menurut Edward Said dalam bukunya yang berjudul Orientalism, Orientalisme adalah cara bangsa Barat (Occident) mendominasi, menstrukturasi, dan memiliki otoritas terhadap bangsa Timur (Orient) (Said, 1978, p. 3). Karakter Timur atau orient digambarkan sebagai sesuatu yang irasional, rusak akhlak, kekanak-kanakan, mudah ditipu, tidak memiliki energi dan inisiatif, senang dipuji dan dijilat, penuh intrik, licik, kejam terhadap binatang, bodoh, terbelakang, pembohong, malas, penuh prasangka buruk, mudah dikalahkan, bertele-tele dalam menyampaikan buah pikirannya dan berbeda dari bangsa Barat. Sedangkan bangsa Barat digambarkan dengan karakter yang rasional, jelas, tepat, mulia, penuh kebajikan, matang, digjaya, jernih dalam mengungkapkan buah pemikirannya dan normal (Said, 1978, p.40-41).

\subsection{Representasi}

Representasi merupakan suatu praktik yang penting dalam memproduksi kebudayaan. Seseorang dikatakan berasal dari kebudayaan yang sama jika manusiamanusia yang ada memiliki dan berbagi pengalaman yang sama, berbagi kode kebudayaan yang sama, berbicara dengan 'bahasa' yang sama dan saling berbagi konsep yang sama pula. Representasi digunakan sebagai sebuah pemaknaan dari tanda-tanda yang tersedia seperti: film, video, fotografi, dialog, tulisan, dan sebagainya. Singkatnya, representasi merupakan produksi makna lewat bahasa, baik itu simbol tertulis, lisan, maupun gambar. Merepresentasikan sesuatu berarti menampilkan sesuatu di pemikiran melalui deskripsi ataupun imajinasi.

\subsection{Video Musik}

Musik dapat dimasukkan dalam suatu bentuk komunikasi massa, karena memiliki beberapa unsur, karakteristik dan fungsi yang sama dengan komunikasi massa. Lirik merupakan pesan yang ingin disampaikan pada audience-nya melalui sebuah media tertentu. Pesan yang ingin disampaikan oleh musik juga bersifat linear dimana hubungan antara komunikator dan komunikannya bersifat searah.

Selain itu, komunikator atau artis, tidak mengenal komunikannya yang terdiri dari berbagai kalangan dan lapisan susunan masyarakat yang berbeda pula. Segala bentuk pesan yang disampaikan komunikan pada komunikator, baik itu berupa feedback dari lagu atau video, ataupun pesan berupa komplain, biasanya melalui sebuah proses yang didalamnya terdapat banyak pihak yang juga terlibat, seperti tim manajemen misalnya. Terlihat pula kesamaan antara musik dan komunikasi massa dari segi fungsi. Secara umum, musik dapat digunakan untuk memberikan informasi seperti masalah sosial, ekonomi, politik ataupun pendidikan. Sedangkan secara khusus, musik juga dapat digunakan sebagai sarana persuasi.

Video musik atau Music Video (MV) adalah sebuah film lagu, kombinasi dari lagu seorang musisi atau grup dengan gambar visual. Video musik sangat berperan mengenalkan kepada publik tentang si artis, atau membantu mengarahkan persepsi publik tentang si artis. Gambar penuh makna, spesial efek, dan editing adalah elemen penting dari video musik. Gaya dari video musik bisa mencerminkan atau memvisualisasikan suasana dari tema lagu. 


\section{METODE}

\subsection{Konseptualisasi Penelitian}

Jenis penelitian ini merupakan penelitian deskriptif kualitatif yang menggambarkan fenomena atau kenyataan sosial yang ada. Tujuan studi deskriptif adalah melaksanakan aspek-aspek yang relevan dengan fenomena yang diamati (Silalahi, 2003, p. 5556). Sedangkan penelitian kualitatif dapat didefinisikan sebagai penelitian yang bertindak sebagai alat pengumpul dan penafsir data.

Metode penelitian yang digunakan metode Semiotika. Semiotika merupakan sebuah studi yang memfokuskan pada tanda dan cara tanda-tanda itu bekerja (Sobur, 2004, p. 128). John Fiske membagi semiotika televisi kedalam beberapa kode-kode yang dimasukkan kedalam tiga level, yaitu level realitas, level representasi dan level ideologi (Fiske, 1987, p.5).

\section{3,2 Subjek Penelitian}

Subjek dari penelitian ini adalah tampilan dari video musik "From Yesterday" dari Thirty Seconds to Mars sendiri. Sedangkan objek penelitiannya adalah penggambaran orientalisme yang ada dalam video musik From Yesterday.

\section{ANALISIS DATA}

Ada beberapa tahapan-tahapan analisis Semiotika yang dilakukan, yaitu (1) Mendefinisikan objek analisis, (2) Mengumpulkan teks, (3) Menjelaskan temuan data, (4) Membenturkan temuan data dengan kode-kode Orientalisme yang terdapat dalam teks tersebut, (5) Menafsirkan teks.

\subsection{Temuan Data}

\section{Penggambaran Tokoh Timur}

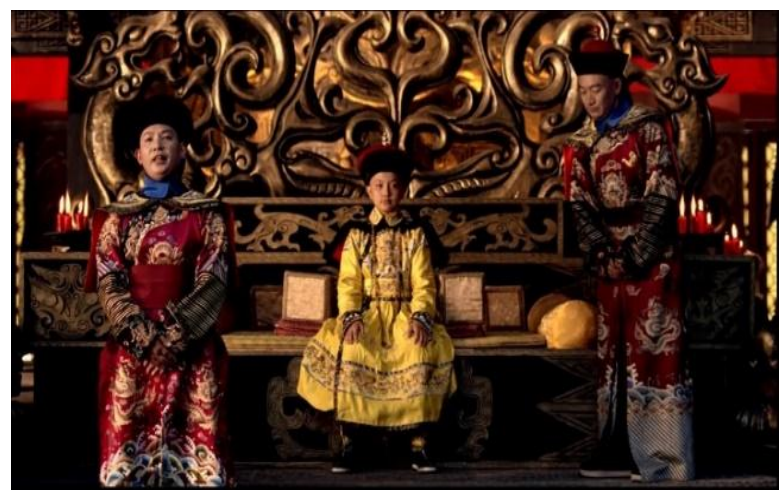

Sumber: Video Klip from Yesterday

Gambar 1. Kostum kaisar dalam video "From Yesterday"
Di dalam video musik From Yesterday ini, terdapat tokoh kaisar bersosok anak kecil, yaitu Henry Pu Yi. $\mathrm{Pu}$ Yi merupakan kaisar terakhir Cina sebelum berubah menjadi negara republik. Ia menjabat pada tahun 1908 di era Dinasti Qing, saat berusia tiga tahun kala itu. Berdasarkan kode kostum dari level realita kode-kode televisi John Fiske, pakaian yang digunakan oleh kaisar dari awal hingga akhir video adalah pakaian kebesaran kaisar yang berwarna kuning. Di Cina, warna kuning melambangkan kebahagiaan dan kegembiraan. Namun di negara Barat warna kuning menggambarkan kebusukan (decay) dan pengecut (cowardice). Selain itu kuning juga menggambarkan kesan warning effect. Pembuat video yang notabene merupakan orang Barat seakan memberikan peringatan bahwa tokoh Timur yang ada di dalam video ini akan menunjukkan kebusukan dan sisi pengecut.

\section{Penggambaran Tokoh Barat}

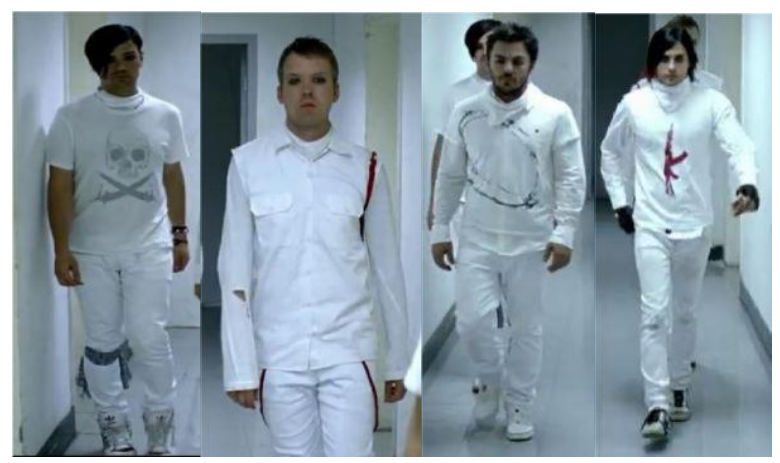

Sumber: Video Klip from Yesterday

Gambar 2. Kostum Thirty Second to Mars di awal video "From Yesterday"

Penampilan para personil 30STM pertama kali muncul dengan latar mereka berada di North America atau Amerika Utara. Mereka berada di ruangan serba putih dan mengenakan kostum berupa pakaian berwarna serba puti. Kostum yang digunakan oleh para personil 30STM pun memiliki beberapa gambar di baju mereka seperti senapan (Jared), kawat berduri (Shannon), tengkorak (Tomo), dan tali merah pada lengan baju (Matt). Warna putih dalam konteks budaya Barat kerap diasosiasikan dengan light atau terang, kebaikan, kemurnian (innocence), kejernihan (purity), bersih dan sempurna (perfection). Berbanding terbalik dengan hitam, putih merepresentasikan sebuah kesuksesan. Penempatan warna serba puth baik di latar, lighting dan kostum para personil 30STM berada (North America), seperti ingin mengatakan bahwa Barat dalam hal ini Amerika atau para personil 30STM merupakan sosok yang baik, murni, jernih, bersih, sukses, dan sempurna (Changing Minds.org, n.d.). 


\section{Penggambaran Lingkungan}



Sumber : Video Klip from Yesterday

Gambar 3. Perbedaan penggambaran lingkungan di video "From Yesterday"

Terdapat perbedaan signifikan perihal latar lingkungan. Ketika personil 30STM berada di Amerika, ruangan bernuansa serba putih. Sementara ketika berada di Cina, kostum dan latar berubah menjadi hitam. Hal ini menunjukkan bahwa para personil 30STM mengalami transisi dari putih ke hitam. From light to dark. From Good to Bad. Hal ini didukung dengan dress atau kostum 30STM yang berubah dari serba putih menjadi serba hitam ketika mereka berada di Cina.

\section{Penggambaran Budaya}

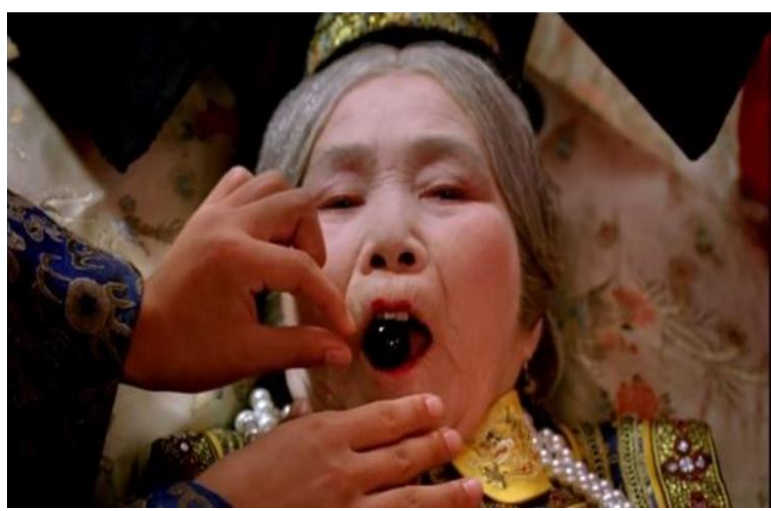

Gambar 4. Penggambaran budaya video From Yesterday

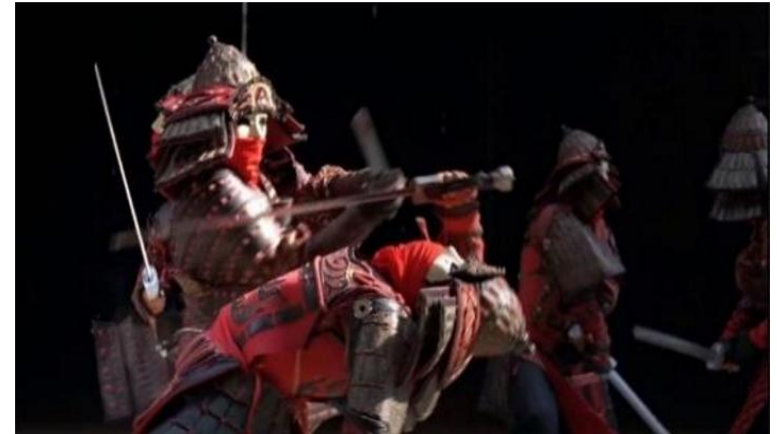

Sumber: Video Klip From Yesterday

Gambar 5. Gambaran budaya Timur dalam video "From Yesterday"

Terdapat beberapa budaya yang menunjukkan penyiksaan oleh Bangsa Cina di video From Yesterday, seperti memasukkan bola merkuri kedalam mulut, perempuan yang dipasung kepalanya, pria dewasa yang mencambuki dirinya sendiri, dan perempuan dewasa yang menyusui pria dewasa. Di akhir video juga terdapat pertarungan pedang yang lebih mirip pertarungan pedang Samurai asal Jepang. Padahal di Cina tidak ada yang namanya pertarungan pedang.

\subsection{Analisis}

\section{Stereotype bangsa Timur dari cara pandang Barat}

Pemilihan tokoh kaisar berupa anak kecil seakan menggambarkan bagaimana sosok anak kecil memimpin sebuah negara yang berujung dengan kekacauan dan kehancuran pada bangsa itu. Hal ini sesuai dengan pernyataan orientalisme yang mengatakan bahwa stereotype timur adalah irasional, kekanak-kanakan, bodoh, kejam dan penuh intrik.

Terdapat beberapa tokoh lain yang juga dimunculkan seperti pelayan kaisar, prajurit kekaisaran. Mereka adalah orang yang berada dibawah pimpinan atau tekanan dari pemimpinnya. Dari kode kostum, dapat diketahui bahwa pelayan raja yang muncul dalam video musik From Yesterday adalah kostum dari eunuch atau orang kasim pada masa pemerintahan Dinasti Qing, yang menjadi pelayan dengan cara dikebiri.

Selain munculnya stereotype-stereotype terhadap karakter Timur, peneliti juga menemukan bahwa pandangan Barat terhadap Timur juga cenderung mencampuradukkan beberapa budaya dari bangsa Timur. Hal itu terlihat dari munculnya kostum dan kegiatan petarungan pedang yang khas negara Jepang, yaitu Samurai. Padahal, latar tempat video From Yesterday dibuat adalah di Cina. Lewat video ini, 
dapat terlihat pandangan Barat terhadap kebudayaan Timur yang seolah-olah sama semua. Pembuat video yang notabene merupakan orang Barat mengabaikan latar belakang sejarah maupun asal-usul dari tiap kebudayaan (Cina \& Jepang) dan meleburkannya menjadi satu demi estetika dan eksotisme video mereka. Hal ini sesuai dengan apa yang telah dikaji Edward Said pula, yaitu bagaimana Timur hadir secara eksotik dalam pandangan Barat.

\section{Penggambaran Dominasi Barat (Occident) ter- hadap Timur (Orient)}

Penggambaran dominasi Barat banyak ditemukan dalam tokoh para personil 30STM. Seperti adegan ketika mereka melakukan beberapa tradisi Cina, yaitu Kowtow. Kowtow merupakan bentuk penghormatan paling tinggi yang ditunjukkan dengan bentuk sujud, berlutut dan membungkukkan kepala dan biasanya disertai dengan posisi kepala yang sampai menyentuh tanah (Hsu, 1970, p. 152). Para personil 30STM membungkukkan badannya di depan hadapan Kaisar Cina, namun kepala mereka tidak sampai menyentuh lantai atau tanah seperti yang seharusnya. Dengan kata lain, mereka tidak sepenuhnya menghormati kaisar. Hal ini menimbulkan kesan bahwa Barat melakukan menghormati Timur, namun bukan berarti 'tunduk'.

Menariknya terdapat adegan dimana personel 30STM membuat cara penghormatan tersendiri yang mana berbeda dari cara mereka memberi hormat kepada kaisar.

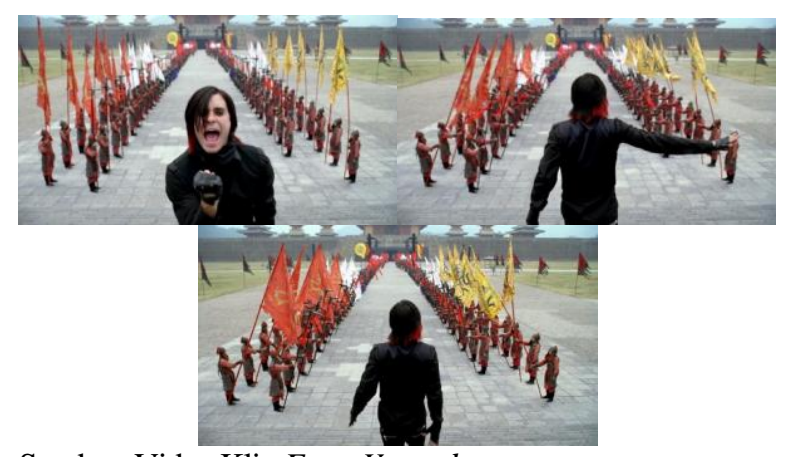

Sumber: Video Klip From Yesterday

Gambar 5. Gesture khas kaum Nazi yang dilakukan oleh Jared Leto

Gerakan atau gesture yang dilakukan oleh Jared Leto identik dengan gerakan penghomatan kaum Nazi pada zaman pemerintahan Adolf Hitler. Gerakan ini diadaptasi para partai Nazi sebagai bentuk ketaatan atau kepatuhan kepada pemimpinnya. Menariknya ketika Jared mengayunkan tangannya ke samping layaknya Hitler sang diktator, para prajurit Cina meresponi dengan penuh ketundukkan. Hal ini menandakan bahwa Jared Leto (Barat) berkuasa atas para prajurit Cina (Timur).

Pada momen ini, lirik "on his face is the map of the world" dinyanyikan berulang kali. Sepanjang video, penginterpretasian lirik ini adalah bagaimana kaisar Cina memiliki segalanya (kekayaan dan kekuasaan) atau berada 'di atas dunia'. Akan tetapi, kini, penempatan adegan salute di lirik ini, dapat dimaknai sebagai para rakyat Cina (Timur) yang sebegitu berkuasa dan kaya masih tunduk terhadap Barat.

\section{INTERPRETASI}

Berdasarkan temuan dan analisis data yang telah dilakukan, peneliti memaknai bahwa orientalisme dalam video musik From Yesterday terlihat dari dua hal besar, yaitu stereotype Timur dari sisi negatif semakin dikokohkan dan Barat masih mendominasi Timur baik dari segi budaya, tokoh maupun lingkungan. Hal tersebut tidak terlihat secara eksplisit di dalam video, melainkan terimplisit di setiap lambanglambang, budaya, kostum, dan tokoh yang ada.

Stereotype Timur yang irasional, rusak akhlak, kekanak-kanakan, mudah ditipu, tidak memiliki energi dan inisiatif, senang dipuji dan dijilat, penuh intrik, licik, kejam terhadap binatang, bodoh, terbelakang, pembohong, malas, penuh prasangka buruk, mudah dikalahkan, bertele-tele dalam menyampaikan buah pikirannya dan sangat berbeda dari bangsa Barat tergambarkan dengan jelas melalui karakter dan aktivitas pemimpin dan anak buahnya.

Dominasi Barat yang jelas terlihat adalah cara para personil 30STM menghadapi pertarungan, memimpin prajurit Cina, perilaku ketika berhadapan dengan pemimpin bangsa Cina. Sifat superior bangsa Barat terlihat kental dalam video musik From Yesterday ini meskipun mereka adalah minoritas yang berada tempat asing.

Pencampuradukkan berbagai budaya Timur tanpa disertai penggambaran maksud yang jelas dalam video musik From Yesterday, penggambaran latar belakang sejarah dan budaya Timur tidak sepenuhnya digambarkan dengan benar. Hal tersebut terlihat dari munculnya atribut-atribut pakaian Samurai yang digunakan oleh para prajurit Cina, pertarungan pedang yang dilakukan prajurit Cina.

Hegemoni budaya juga terlihat dari bagaimana lambang-lambang Illuminati yang dibawa Barat ke 
Timur dimunculkan dalam video ini, baik secara sengaja maupun tidak sengaja. Penggambaran sosok Barat yang dominan, stereotype Timur yang muncul, dan pencampuradukkan budaya yang ada seperti memposisikan Timur sebagai sosok yang inferior di mata Barat. Hal ini menjawab rumusan masalah yang ada, yaitu perihal bagaimana bangsa Timur digambarkan dalam video musik From Yesterday ini.

Lirik lagu From Yesterday juga menggambarkan bangsa timur sebagai bangsa yang inferior. Secara keseluruhan peneliti menafsirkan bahwa video musik ini sarat dengan penggambaran orientalisme yang negatif.

\section{SIMPULAN}

Ada banyak tanda-tanda dominasi bangsa Barat yang ditemukan secara implisit dalam video "From Yesterday" oleh peneliti. Dari tanda-tanda dan lambang yang ditemukan peneliti disimpulkan bahwa adanya pertanda 1) Dominasi Barat terhadap Timur, 2) Stereotype Timur dari pandangan Barat yang semakin dikokohkan, dan 3) Pengabaian sejarah dari budayabudaya Timur yang ada.

Beberapa contohnya pada waktu prajurit Cina merespon dengan taat pada stimulus ayunan tangan ala Nazi yang dilakukan oleh Jared Leto atau ketika para personil 30STM tidak hormat dalam melakukan budaya-budaya Timur seperti tradisi Kowtow ataupun menerima hadiah dengan tangan kanan. Dimasukkannya lambang-lambang Illuminati dalam video musik From Yesterday ini juga seperti ingin mengkokohkan bentuk dominasi Barat dimana Band Thirty Seconds to Mars seperti ingin membawa New World Order-nya yang ada di beberapa video musik mereka sebelumnya, kedalam lingkup Asia.
Sifat superior terlihat kental dalam video musik From Yesterday ini meskipun secara jumlah, tokoh Barat yang digunakan dalam video lebih sedikit daripada tokoh Timur. Selain itu, pencampuradukan budaya terlihat dari munculnya atribut-atribut pakaian Samurai yang digunakan oleh para prajurit Cina. Diketahui pula dari temuan data bahwa di Cina sendiri sebenarnya tidak ada tradisi pertarungan pedang. Pertarungan pedang yang ada di video musik From Yesterday lebih identik dengan pertarungan pedang ala Samurai (Jepang). Hal ini menunjukkan adanya pencampuradukkan dua budaya Timur yang berbeda yaitu Cina dan Jepang. Produser video seperti tidak memperdulikan kebenaran latar sejarah dari masing-masing budaya dan mencampuradukkannya menjadi satu demi kepentingan estetika dan eksotisme video. Hal ini sesuai dengan pandangan orientalisme yang memandang Timur sebagai sesuatu yang eksotik baik bagi Barat maupun Timur sendiri.

\section{DAFTAR PUSTAKA}

Fiske, John. (1987). Television Culture: Popular Pleasure and Politics. New York: Metheun \& Co. Ltd.

Hernandez, H. R., \& Steen, S. (2006). AfroAsian Encounters. New York: NYU Press.

Leahey, A. (2013, Mei 18). Biography. Retrieved from All Music: http://www.allmusic.com/artist/ thirty-seconds-to-mars-mn0000485365/biography

Park, Jane Chi Hyun. (2010). Yellow Future: Oriental Style in Hollywood Cinema.

Said, E. W. (1978). Orientalism. New York: Vintage Book.

Silalahi, G.A. (2003). Metodologi Penelitian dan Studi Kasus. Sidoarjo: Citra Media.

Sobur, Alex. (2004). Semiotika Komunikasi. Bandung: PT. Remaja Rosdakarya. 